\title{
Seed Coating Increase Broccoli Nutrient Content and Availability after Cooking
}

\author{
Micaela Carvajal ${ }^{1}$, M. Carmen Martinez-Ballesta ${ }^{1}$, Diego A. Moreno ${ }^{2}$, Javier Bernabeu ${ }^{3}$ \\ \& Cristina García-Viguera ${ }^{2}$ \\ ${ }^{1}$ Plant Nutrition Department, CEBAS-CSIC, Espinardo, Murcia, Spain \\ ${ }^{2}$ Food Science Technology Department, CEBAS-CSIC, Espinardo, Murcia, Spain \\ ${ }^{3}$ Sakata Seed Iberica, Pl. Poeta Vicenta Gaos, Valencia, Spain \\ Correspondence: Micaela Carvajal, Plant Nutrition Department, CEBAS-CSIC, Espinardo, 30100 Murcia, Spain. \\ E-mail: mcarvaja@cebas.csic.es
}

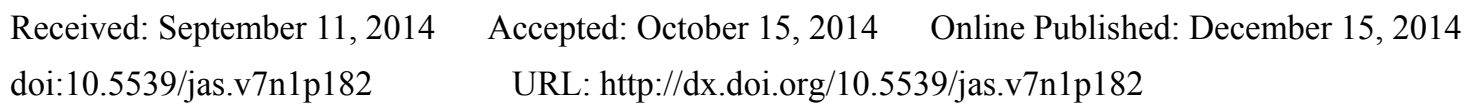

\begin{abstract}
Broccoli is a rich source of minerals which play an important role in health. From farm to food there are many processes that affect the mineral nutritional quality. As the quality of the seeds is the basis for the successful production, the protection of seeds by coating is studied to improve the seed quality and maintenance during storage. Also, the studies about the implication in the development of the plants are carried out. For that, the influence of seed capsulation on yield, mineral content, $\mathrm{CO}_{2}$ fixation and gas exchange was determined. The results showed that capsulation treatment improves germination and vegetative growth and production. This may be due to greater absorption of $\mathrm{N}$ and $\mathrm{Fe}$ and higher $\mathrm{C}$ fixation. When inflorescences were cooked, there was a greater loss of mineral nutrients with high pressure and microwave, and lower loss with steaming.
\end{abstract}

Keywords: broccoli, cooking methods, $\mathrm{CO}_{2}$ fixation, human health, mineral nutrition, seeds coating

\section{Introduction}

Nowadays one of the most important challenges for the agriculture is to enhance the food production and providing almost all the essential minerals and organic nutrients to humans in order to maintain health and organ functions. Humans need more than 22 mineral elements, some of them are required in large amounts, but others, such as $\mathrm{Fe}, \mathrm{Zn}, \mathrm{Cu}$, I and $\mathrm{Se}$, are required in trace amounts because higher concentrations can be harmful (Welch \& Graham, 2004; Grusak \& Cakmak, 2005). Although vegetables constitute the main source of minerals for the human diet, vegetables do not always contain enough amounts of these essential nutrients to meet dietary requirements (Welch et al., 1997).

Broccoli, contains high amounts of bioactive compounds and vitamins but also high content of minerals that can be an important supplement in nutrient-incomplete diets (Agte et al., 2000). The main mineral elements (Na, K, $\mathrm{Ca}, \mathrm{Mg}, \mathrm{Cl}, \mathrm{S}, \mathrm{N}$ and $\mathrm{P}$ ) present in broccoli are essential for human beings in amounts $>50 \mathrm{mg} /$ day, while trace elements ( $\mathrm{Fe}, \mathrm{Zn}, \mathrm{Cu}, \mathrm{Mn}, \mathrm{I}, \mathrm{F}, \mathrm{Se}, \mathrm{Cr}, \mathrm{Mo}, \mathrm{Co}, \mathrm{Ni}$ ) are essential in concentrations of $<50 \mathrm{mg} \mathrm{day}^{-1}$. These main and trace elements have very varied functions, e.g., as electrolytes, as enzymes constituents and as building materials, e.g. in bones and teeth.

Magnesium ( $\mathrm{Mg}$ ) acts as a $\mathrm{Ca}$ antagonist on vascular smooth muscle tone and on post-receptor insulin signaling and it has been related with muscles and nerves excitability (Huskisson et al., 2007). Potassium (K) and sodium (Na) play important role in the maintenance of the balance of physical fluids system (Sobotka et al., 2008). The major function for iron $(\mathrm{Fe})$ is related to the synthesis of haemoglobin and myoglobin. Therefore, a severe iron deficiency results in hypochromic anaemia (Huskisson et al., 2007). Cupper (Cu) is necessary for the development of connective tissue and nerve coverings (myelin sheath) and also participates in the Fe metabolism (Huskisson et al., 2007; Shenkin, 2008). The main physiological function of manganese (Mn) is related with metabolism of carbohydrates and gluconeogenesis (Shenkin, 2008), while zinc ( $\mathrm{Zn})$ is required for glucose use and insulin secretion (Lukaski, 2004).

The level of minerals in vegetables depends on a number of factors including genetic properties of the crop species, climatic conditions, soils characteristics and the degree of maturity of plant at the moment of harvesting. 
New technologies, like the use of coating seed technology with soluble polymers is starting to be proposed due to the demand of improving the interaction soil-plant system. This technology has been implemented to be used as antibacterial or antifungal protection against diseases (Someya et al., 2007). However, the coating itself could affect the efficiency of the germination and the primary developing process (Almeida \& Rocha, 2008) with later effect on adult plant.

Broccoli, as other cole crops, is rich in the previously mentioned minerals anions and cations, but the effect of capsulation of seed on the mineral composition of this vegetable has not been studied neither the effect of cooking on the final mineral concentration in food. The mineral content might fluctuate depending on genetic factors, climatic conditions, agricultural procedures, composition of the soil, etc, but also changes occur in the processing of the raw material. In this aspect, broccoli is frequently consumed as a cooked vegetable and some previous studies with other phytochemicals have demonstrated that domestic procedures (cooking, storage, etc.) play an important role in final food quality (Vallejo et al., 2002, 2003a, 2003b).

Therefore, the aim of this study is determining the growth, carbon fixation, mineral composition and gas exchange parameters of broccoli grown from coating seeds, and the effect of different domestic cooking procedures (steaming, high pressure boiling, and microwaving) on mineral content.

\section{Materials and Methods}

\subsection{Plant Material and Growth Conditions}

The experiment was carried out with Brassica oleraceavar. italica, cv Parthenon seedlings obtained from a commercial nursery for horticultural plants in Murcia (Spain). All the seeds were commercial and provided by SAKATA. The experiment was conducted during the spring period in soil of the CEBAS-CSIC "La Matanza" Experimental Farm (Santomera, Murcia, SE Spain), under a semi-arid Mediterranean climate.

Daily mean temperature and relative humidity were recorded every 10 min using dataloggers (AFORA SA, Barloworld Scientific, Murcia, Spain). The humidity was 50/80\% (day/night) and the temperature varied from $21 / 9{ }^{\circ} \mathrm{C}$ (day/night). A total of 360 plants, 180 per treatment (control and capsule) were planted in a $300 \mathrm{~m}^{2}$ plot with randomized block design. All plants were drip irrigated with a diluted (1:4) Hoagland nutrient solution (2 $\left.\mathrm{dS} \mathrm{m}{ }^{-1}\right): \mathrm{KNO}_{3}\left(6 \mathrm{mmol} \mathrm{L}^{-1}\right), \mathrm{Ca}\left(\mathrm{NO}_{3}\right)_{2}\left(4 \mathrm{mmol} \mathrm{L}^{-1}\right), \mathrm{NH}_{4} \mathrm{H}_{2} \mathrm{PO}_{4}\left(1 \mathrm{mmol} \mathrm{L}^{-1}\right), \mathrm{MgSO}_{4}\left(1 \mathrm{mmol} \mathrm{L}^{-1}\right), \mathrm{KCl}(50$

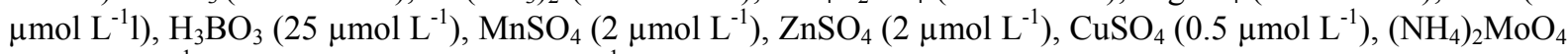
$(0.5 \mu \mathrm{mol} \mathrm{L}-1)$ and Fe-EDDHA $\left(20 \mu \mathrm{mol} \mathrm{L}^{-1}\right)$.

The plants were harvested 90 days after transplanting the seedlings. The inflorescences were separated from the rest of the plant, which was divided into leaves, stems, and roots and weighed.

\subsection{Mineral Elements}

The concentrations of $\mathrm{Ca}, \mathrm{Mg}, \mathrm{K}$ and $\mathrm{Na}$ were analyzed on samples of plant material which had been ground finely in a mill grinder after drying at $65{ }^{\circ} \mathrm{C}$ to constant weight. The samples were digested in a microwave (CEM Mars Xpress, North Carolina, USA), reaching $200{ }^{\circ} \mathrm{C}$ in $20 \mathrm{~min}$ and holding at this temperature for $2 \mathrm{~h}$, using $5 \mathrm{ml}$ of concentrated $\mathrm{HNO}_{3}, 17 \mathrm{ml}$ of $\mathrm{H}_{2} \mathrm{O}$, and $3 \mathrm{ml}$ of $\mathrm{H}_{2} \mathrm{O}_{2}$. The concentrations of the elements were measured by inductively coupled plasma spectrometry (Iris Intrepid II, Thermo Scientific, Waltham, MA, USA). The solution to analyse is conducted by a peristaltic pump though a nebulizer into a spray chamber, leading into argon plasma. As a consequence an alternate magnetic field is induced that accelerate electrons into a circular trajectory. Due to collision between the argon atom and the electrons ionisation occurs, giving rise to stable plasma. Therefore, atomisation and ionisation of the sample takes place. Due to the thermic energy taken up by the electrons, they reach a higher excited state that is liberated when the electrons drop back to ground level energy. Each element has an own characteristic emission spectrum. The emitted photons in different frequencies are captured simultaneously on a CCD chip (Charged Coupled Device).

\subsection{Carbon Analysis}

The plants were dried into an oven at $65{ }^{\circ} \mathrm{C}$ until constant weight, to determine the dry weight and to dry the samples of the different plant parts before grinding them in a laboratory analytical mill (IKA A10 model).

The total carbon contents were analyzed in leaves, stems, fruits, and roots using a $\mathrm{CN}$ analyzer (Thermo-Finnigan 1112 EA elemental analyzer; Thermo-Finnigan, Milan, Italy). Oxygen combusts solid samples when ignited using helium as carrier. The first furnace, set to $950^{\circ} \mathrm{C}$, holds a chromium(III) oxide column which oxidizes carbon into carbon dioxide. The carbon dioxide gas flows through a magnesium perchlorate column which removes water before the gas enter the gas chromatograph column at $50{ }^{\circ} \mathrm{C}$ to be separated by retention rates. The gases are sensed by the thermal conductivity detector (TCD). The curves are integrated and used to 
calculate the weight percent of carbon in the sample.

The results $\% \mathrm{C}$ data were used for calculating $\mathrm{g}$ of $\mathrm{CO}_{2}$ fixed per plant. For calculation of $\mathrm{g}$ of $\mathrm{CO}_{2}$ fixed per square meter of each crop, plant distance (P.D.) was taken into account (P.D. broccoli $=3.5$ plants $\mathrm{m}^{-2}$ ).

\subsection{Leaf Gas Exchange Parameters}

Net assimilation of $\mathrm{CO}_{2}\left(\mathrm{ACO}_{2}\right)$ and stomatal conductance $\left(\mathrm{G}_{\mathrm{s}}\right)$, were measured using a portable photosynthesis system (model LCA-4, ADC Bioscientific Ltd., Hoddesdon, UK) and a PLC-4N leaf chamber $\left(11.35 \mathrm{~cm}^{2}\right)$, configured to an open system. The abaxial stomatal conductance was measured on the most-recent, fully-expanded leaves. The measurements were carried out at 09:00 to 12:00 h, to avoid the high temperatures and low humidity of the afternoon, and only on clear days, to minimize the impact of variations in light intensity.

\subsection{Cooking Experiments}

For analytical purposes a total of 4 inflorescences were randomly selected, comprising four replicates for each treatment. The edible portions were washed and cut $(\sim 3 \mathrm{~cm}$ diameter and $\sim 1 \mathrm{~cm}$ stalk).

In order to compare the possible influence of mineral composition of tap water different cooking procedures were done with deionised water. Boiling and steaming (S) were applied using a pressure cooker (Rapid-express, Fagor, Guipuzcoa, Spain) containing $50 \mathrm{~g}$ of freshly cut raw broccoli and $50 \mathrm{ml}$ of deionised water, using high pressure cooking (HPD). The inflorescences were fully dipped in the water and cooked for 2 min, whilst they were suspended above the boiling water for 2 min for steaming. A microwave oven (Samsung, Cleveland, UK) operating at full power $(1000 \mathrm{~W})$ for 2 min was used for microwaving (MW), with the same amount of broccoli and cooking water as above. Prior to the cooking processes, time/pressure relationships were established as in Vallejo et al. (2003a, 2003b).

\subsection{Mineral Content in Cooked Inflorescences}

Cooked samples were dried at $65^{\circ} \mathrm{C}$ for 5 days and ground. Digestions and measurements were done as for fresh material

\subsection{Statistical Analysis}

Data were statistically analyzed using the SPSS 7.5 software package, by analysis of variance (ANOVA) and by Tukey's Multiple Range Significant differences were determined at $p<0.05$.

\section{Results}

The germination rate was recorded daily and it was similar in both treatments control and capsulated (data not shown). However, the final level of germination after 15 days reached the $84 \%$ in control while in capsulated was $90 \%$.

The growth expressed in fresh and dry weight (Table 1) was higher in plants from capsulated seeds. The increase in both fresh and dry weight was due to the higher values in leaves and inflorescence. The humidity was higher in stems, leaves and inflorescence than in roots, but there were no significant differences in $\%$ humidity between control and capsulated. 
Table 1. Results of fresh and dry weight, \% humidity and $\mathrm{CO}_{2}$ fixation of broccoli, cv Parthenon grown from control and capsulated seeds. Data are mean $(n=10) \pm S E$

\begin{tabular}{|c|c|c|c|c|c|c|}
\hline Control & $\begin{array}{l}\text { Fresh Weigh } \\
\left(\text { g plant }^{-1}\right)\end{array}$ & $\begin{array}{l}\text { Dry Weigh } \\
\left.\text { (g plant }^{-1}\right)\end{array}$ & Humidity (\%) & $\% \mathrm{C}$ & $\begin{array}{l}\text { Total C } \\
\left(\text { g plant }^{-1}\right)\end{array}$ & $\begin{array}{l}\text { Total } \mathrm{CO}_{2} \text { Fixation } \\
\left(\text { g plant }^{-1}\right)\end{array}$ \\
\hline \multicolumn{7}{|l|}{ Plant (Inputs) } \\
\hline Roots & $457.0 \pm 26.3$ & $85.4 \pm 5.3$ & $81.3 \pm 6.2$ & $41.5 \pm 1.6$ & $35.4 \pm 2.6$ & $129.9 \pm 8.3$ \\
\hline Stems & $600.9 \pm 35.9$ & $63.0 \pm 7.5$ & $89.5 \pm 4.3$ & $41.5 \pm 1.5$ & $26.1 \pm 1.7$ & $95.9 \pm 5.6$ \\
\hline Leaves & $207.9 \pm 14.8$ & $22.1 \pm 1.5$ & $89.4 \pm 2.5$ & $42.0 \pm 2.2$ & $9.3 \pm 0.3$ & $34.1 \pm 2.7$ \\
\hline Inflorescence & $229.4 \pm 12.4$ & $24.6 \pm 1.6$ & $89.3 \pm 3.8$ & $42.7 \pm 2.0$ & $10.5 \pm 0.5$ & $38.5 \pm 2.5$ \\
\hline Total & $1495.1 \pm 48.6$ & $195.1 \pm 13.4$ & & & $81.4 \pm 7.6$ & $298.3 \pm 20.7$ \\
\hline Capsulated & $\begin{array}{l}\text { Fresh Weigh } \\
\left(\mathrm{g} \mathrm{plant}^{-1}\right)\end{array}$ & $\begin{array}{l}\text { Dry Weigh } \\
\left.\text { (g plant }^{-1}\right)\end{array}$ & Humidity (\%) & $\% \mathrm{C}$ & $\begin{array}{l}\text { Total C } \\
\left(\text { g plant }^{-1}\right)\end{array}$ & $\begin{array}{l}\text { Total } \mathrm{CO}_{2} \text { Fixation } \\
\left(\text { g plant }^{-1}\right)\end{array}$ \\
\hline \multicolumn{7}{|l|}{ Plant (Inputs) } \\
\hline Roots & $460.0 \pm 28.6$ & $86.4 \pm 6.1$ & $81.2 \pm 4.2$ & $42.5 \pm 2.2$ & $36.7 \pm 1.7$ & $134.6 \pm 2.5$ \\
\hline Stems & $608.7 \pm 30.2$ & $62.3 \pm 2.5$ & $89.1 \pm 3.8$ & $42.6 \pm 2.0$ & $26.8 \pm 1.3$ & $98.4 \pm 5.6$ \\
\hline Leaves & $231.4 \pm 15.9$ & $24.5 \pm 0.8$ & $88.9 \pm 5.3$ & $44.5 \pm 1.5$ & $10.9 \pm 0.3$ & $40.0 \pm 1.3$ \\
\hline Inflorescence & $278.6 \pm 8.6$ & $29.1 \pm 1.3$ & $89.6 \pm 2.7$ & $45.1 \pm 1.3$ & $13.1 \pm 0.4$ & $48.0 \pm 2.0$ \\
\hline Total & $1570.9 \pm 56.2$ & $202.9 \pm 12.7$ & & & $87.6 \pm 2.6$ & $321.0 \pm 16.7$ \\
\hline
\end{tabular}

The \% C (Table 1) was very stable comparing each organ of the plant in control treatment. However, in plants from capsulated seeds, there were an increase in leaves and inflorescence in comparison to roots and stems. Therefore, when total carbon or total $\mathrm{CO}_{2}$ fixation was calculated, a significant increase was observed in capsulated due to the increase in both growth and $\mathrm{C}$ composition in leaves and inflorescence comparing to no capsulated plants.

The gas exchange was measured at sunrise and midday (Figure 1). The net assimilation of $\mathrm{CO}_{2}\left(\mathrm{ACO}_{2}\right)$ and stomatal conductance $\left(\mathrm{G}_{\mathrm{s}}\right)$ showed only slight differences between the two times of measurement. However, both parameters were higher in capsulated plants than in control.

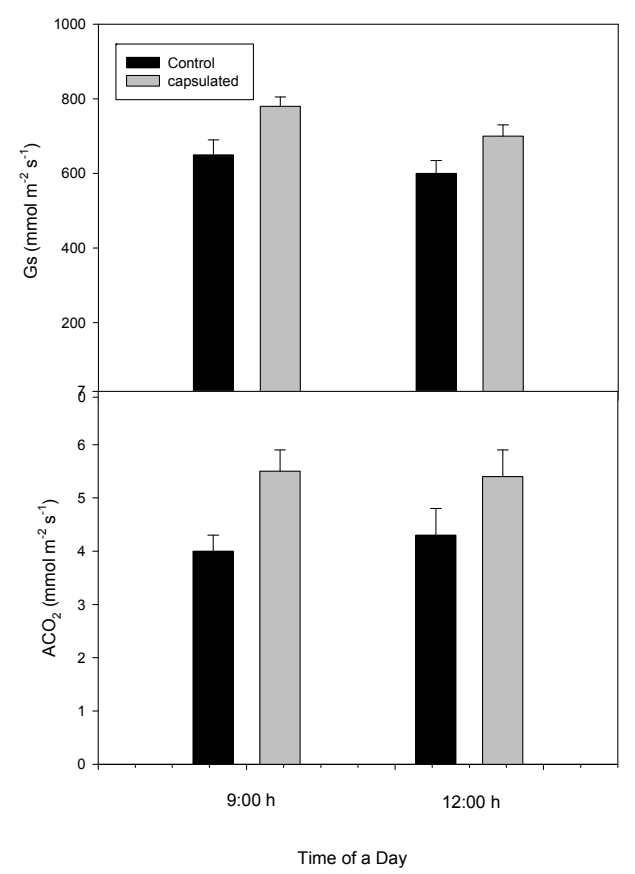

Figure 1. Net assimilation of $\mathrm{CO}_{2}\left(\mathrm{ACO}_{2}\right)$ and stomatal conductance $\left(\mathrm{G}_{\mathrm{s}}\right)$ in of broccoli, cv Parthenon grown from control and capsulated seeds. Data are means of five plants \pm SE 
The yield (Figure 2) was measured as number of inflorescence by harvesting date (Figure 2a) and as the weight of the inflorescences (Figure 2b). As it can be observed in Figure 2a, the development of the inflorescences from control plants was earlier than from capsulated during the whole harvesting period. When the total weight of the inflorescences harvested by date was recorded (Figure 2b), it can be observed a slight increase of control inflorescences during the first dates but a higher increase in capsulated inflorescences at the final dates. All that gave a higher final weight for capsulated.

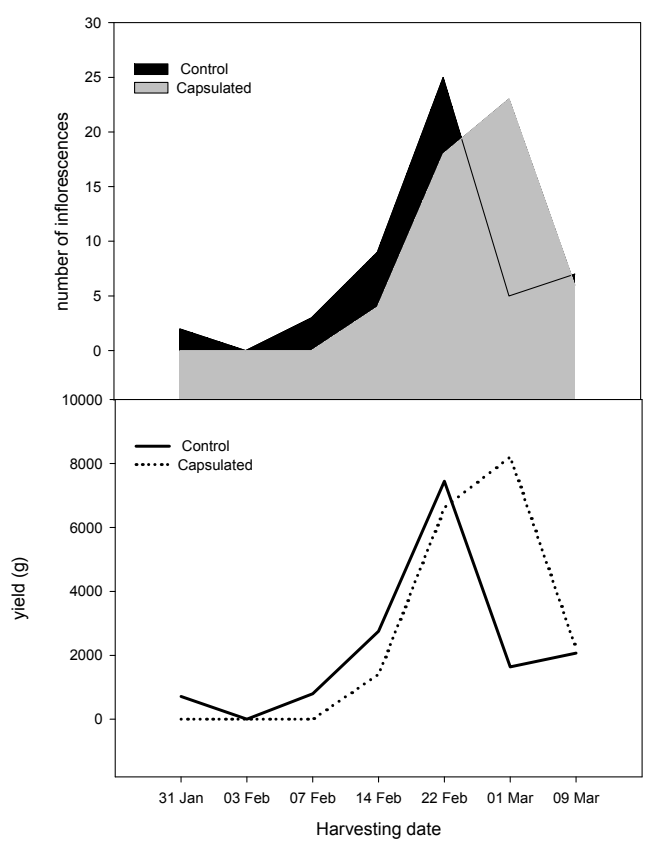

Figure 2. Number of inflorescences and total yield (g) of broccoli, cv Parthenon grown from control and capsulated seeds. Data are obtained from 51 plants

When the mineral composition of the inflorescences was determined (Table 2), it can be observed changes only in some of the elements: N, C and $\mathrm{Ca}$ (macroelements), Fe and $\mathrm{Zn}$ (microelements). In general, except for the Ca, the capsulation of the seeds produced an increase of the referred elements, with no different changes for the rest ( $\mathrm{Na}, \mathrm{K}, \mathrm{Mg}, \mathrm{Cu}$ and $\mathrm{Mn}$ ).

Table 2. Mineral composition of inflorescence (d.w) control and from plants grown from capsulated seeds

\begin{tabular}{lll}
\hline & Control & Capsulated \\
\hline $\mathrm{N}(\mathrm{g} / 100 \mathrm{~g})$ & $1.71 \pm 0.11^{*}$ & $2.54 \pm 0.14^{*}$ \\
$\mathrm{C}(\mathrm{g} / 100 \mathrm{~g})$ & $42.78 \pm 0.61^{*}$ & $45.07 \pm 0.34^{*}$ \\
$\mathrm{Na}(\mathrm{g} / 100 \mathrm{~g})$ & $0.05 \pm 0.001$ & $0.06 \pm 0.002$ \\
$\mathrm{~K}(\mathrm{~g} / 100 \mathrm{~g})$ & $1.87 \pm 0.25$ & $1.95 \pm 0.30$ \\
$\mathrm{Ca}(\mathrm{g} / 100 \mathrm{~g})$ & $2.93 \pm 1.01^{*}$ & $1.88 \pm 0.20^{*}$ \\
$\mathrm{Mg}(\mathrm{g} / 100 \mathrm{~g})$ & $0.13 \pm 0.01$ & $0.11 \pm 0.02$ \\
$\mathrm{Fe}(\mathrm{mg} / \mathrm{Kg})$ & $24.12 \pm 1.51^{*}$ & $33.04 \pm 1.65^{*}$ \\
$\mathrm{Zn}(\mathrm{mg} / \mathrm{Kg})$ & $12.01 \pm 0.12^{*}$ & $23.40 \pm 1.62^{*}$ \\
$\mathrm{Cu}(\mathrm{mg} / \mathrm{Kg})$ & $1.97 \pm 0.23$ & $2.02 \pm 0.17$ \\
$\mathrm{Mn}(\mathrm{mg} / \mathrm{Kg})$ & $104.26 \pm 13.88$ & $92.42 \pm 19.11$ \\
\hline
\end{tabular}

Only the results with significant changes are shown. Data are mean $(n=10) \pm$ SE. Values with $*$ differ significantly according to Tukey's test $(\mathrm{p}=0.05)$. 
In the experiments when broccoli is cooked (Table 3$)$, it can be observed that a daily serving $(200 \mathrm{~g})$ of this vegetable (raw) could provide the total requirement of $\mathrm{K}$ (requirement $782 \mathrm{mg} \mathrm{day}^{-1}$ ), over $80 \%$ of $\mathrm{Mn}$ (requirement $2-5 \mathrm{mg} \mathrm{day}^{-1}$ ), between $15 \%$ and $30 \%$ of daily requirements of Ca (requirement $800-1500 \mathrm{mg}$ day $\left.^{-1}\right), \mathrm{Mg}$ (requirement 300-400 mg day ${ }^{-1}$ ), $\mathrm{Fe}$ (requirement $15 \mathrm{mg} \mathrm{day}^{-1}$ ), and $\mathrm{Cu}$ (requirement 1-1.5 mg day $\mathrm{d}^{-1}$ ), about $10-15 \%$ of $\mathrm{Zn}$ and less than $3 \%$ of $\mathrm{Na}$ (Belizt et al., 2004). As broccoli is eaten cooked, these percentages would vary when the vegetable is cooked under different conditions. Due to the less availability of $\mathrm{Ca}$ in plants from capsulated seeds and higher availability of $\mathrm{Fe}$ and $\mathrm{Zn}$, the \% of the requirements per day were altered The analysis of the main mineral cations in cooked samples, $\mathrm{Na}, \mathrm{K}, \mathrm{Ca}$ and $\mathrm{Mg}$ (Table 3) showed a marked decrease in those broccoli samples cooked under high pressure boiling procedure (around 20\%) and lower decrease in samples cooked with microwave (around 12\%). There was an exception with Na content, which decrease was similar in all the boiling procedure. Steaming cooking produced no significant differences with control with only a slight decrease in $\mathrm{Ca}$ content.

Table 3. Mineral content in $200 \mathrm{~g}$ of fresh broccoli $(\mathrm{Con}=\mathrm{Control}$ and Cap $=$ capsulated in those minerals that showed difference. In the rest, an average is shown) with the percentage of retention after each type of cooking

\begin{tabular}{llllll}
\hline & & $\begin{array}{l}\text { Precooking } \\
\text { (Con/Cap) }\end{array}$ & $\begin{array}{l}\text { High pressure } \\
\text { (Con/Cap) }\end{array}$ & $\begin{array}{l}\text { Vapour } \\
\text { (Con/Cap) }\end{array}$ & $\begin{array}{l}\text { MicroW } \\
\text { (Con/Cap) }\end{array}$ \\
\hline Na & \% retention & 100 & 78 & 100 & 75 \\
& \% RDA & 2.7 & 2.1 & 2.7 & 2.2 \\
\hline \multirow{2}{*}{ K } & \% retention & 100 & 76 & 104 & 86 \\
& \% RDA & 115 & 88 & 119 & 98 \\
\hline \multirow{2}{*}{ Ca } & \% retention & 100 & 78 & 92 & 88 \\
& \% RDA & $21 / 13$ & $16 / 10$ & $19 / 12$ & $19 / 12$ \\
\hline \multirow{2}{*}{ Fe } & \% retention & 100 & 82 & 100 & 88 \\
& \% RDA & 22 & 18 & 22 & 19 \\
\hline \multirow{2}{*}{ \%n retention } & 100 & 63 & 97 & 97 \\
& \% retention & 100 & $15 / 21$ & $23 / 31$ & $23 / 31$ \\
\hline \multirow{2}{*}{ Cu } & \% RDA retention & 100 & 77 & 92 & 85 \\
& \% RDA & 33 & $12 / 23$ & $15 / 29$ & $14 / 27$ \\
\hline \multirow{2}{*}{ \%n } & \% retention & 100 & 23 & 45 & 76 \\
\hline
\end{tabular}

The values are also expressed as the 'Recommended Daily Allowance', RDA (Belizt et al., 2004).

Concerning trace cation $\mathrm{Fe}, \mathrm{Zn}, \mathrm{Cu}$ and $\mathrm{Mn}$ (Table 3), a high decrease was observed in the case of $\mathrm{Fe}$ for pressure cooking but no changes were observed in streaming and microwave. $\mathrm{Zn}$ decreased for all cooking methods ranking from pressure to microwave to streaming with the lower lost. A general decrease was observed for $\mathrm{Cu}$. It is very interesting that the highest decrease resulted in the steamcooking (55\%). However, there was a high reduction in Mn content with high pressure $44 \%$ while the decrease was less (28\%) for streaming and microwave.

\section{Discussion}

Seed coating or capsulation refers to application of layers of solid or semisolid compounds covering the natural seed coat. It usually includes pelting and many seed treatments that adhere around the seed. They are generally used for improve the seed-soil interchange and it usually affect the physiology of the adult plant (Scott, 1989). The effect of the seed coating or capsulation depends on the material used and the germination conditions: soil, moisture, and nutrients (Halmer, 2008). In our experiments, the capsule material (peptides) could slow the speed of hydration or simply protect the seed in the early germination process having a potential effect on metabolism 
and then yield (Figure 2). This could be a similar effect than priming or seed invigoration with the related growth and yield enhancement reported (Farooq et al., 2012). However, the exact mechanism for improving growth and yield by the capsulation should be investigated.

The percentage of carbon content in broccoli plants showed a significant increase in leaves, inflorescence and whole plants from capsulated seeds (Table 1). These results together with the high growth, provided a high capacity for carbon fixation in plants form capsulated seed. Obviously, when plant $\mathrm{CO}_{2}$ fixation (determined per plant) was studied, there was an increase in capsulated due to the higher biomass (Mota-Cadenas et al., 2010). Therefore, besides the higher growth and yield production per plant that capsulated provided, the ecological benefits of a sustainable agriculture is an important factor. The fact that every plant population can sequester $\mathrm{CO}_{2}$ and thus counteract the Greenhouse Effect is becoming an aspect to consider (Geissler et al., 2009).

The rate of photosynthetic $\mathrm{CO}_{2}$ assimilation is generally related to $\mathrm{C}$ content (Brugnoli \& Lauteri, 1990). The results obtained in our plants showed lower values of $\mathrm{ACO}_{2}$ and $\mathrm{G}_{\mathrm{s}}$ in control plants compared with capsulated. The photosynthetic $\mathrm{CO}_{2}$ assimilation has been related to $\mathrm{CO}_{2}$ diffusion to the chloroplasts (Yang \& $\mathrm{Lu}, 2005$; Wilson et al., 2006). In this sense, the changes observed in $\mathrm{ACO}_{2}$ have been reported to be due partly to alterations of $\mathrm{G}_{\mathrm{s}}$ and the consequent changes of the availability of $\mathrm{CO}_{2}$ for carboxylation (Flexas et al., 2008). The fact that in our plants there were a consistent relationship between $\mathrm{ACO}_{2}$ and $\mathrm{G}_{\mathrm{s}}$, could be related to the fact that stomatal opening is dominating in partial $\mathrm{CO}_{2}$ pressure in the leaves and inducing higher assimilation of more $\mathrm{CO}_{2}$. Thereby this could make the $\mathrm{C}$ signatures of the newly-formed plant tissue higher (Groenigen \& Van Kessel, 2002).

Different Brassica vegetables such as cauliflower (B. oleracea var. botrytis), bock choy (B. rapa), broccoli (B. oleracea var. italica) and kale (B. oleracea var acephala) are reported to have a high mineral content (Puupponen-Pimia et al., 2003). In general, Brassica plants have been found to be rich in many minerals including calcium and iron (Miyazawa et al., 2005). When the results obtained in the present work (Tables 2 and 3 ) are compared with those reported for different fresh vegetables, such as watercress, endive, peas, kale, spinach, carrots, potatoes, cabbage, cauliflower, Brussels sprouts, Chinese cabbage, white cabbage, etc (Osler et al., 2001; Kawashima \& Valente-Soares, 2003; Belizt et al., 2004; Koplik et al., 2004; Kmiecik et al., 2007), it could be considered that broccoli is a very good source of these essential minerals for humans beings.

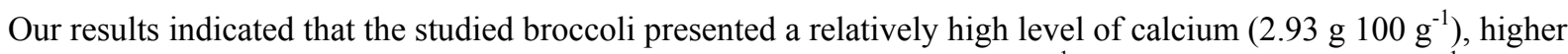

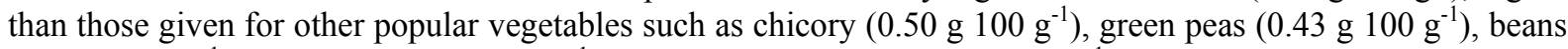

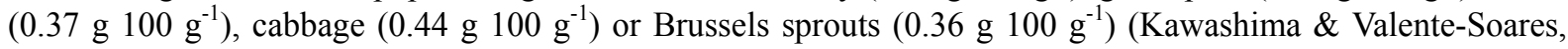
2003; Rickman et al., 2007). Even after capsulation, were slight decrease is observed, broccoli can be regarded as a good source of available calcium and their consumption in the diet may contribute to improve calcium nutrition (Lucarini et al., 1999).

In relation to other minor cations (Table 2), our results revealed high amounts of $\mathrm{Fe}\left(24.12 \mathrm{mg} \mathrm{Kg}^{-1}\right), \mathrm{Zn}(12.01$ $\left.\mathrm{mg} \mathrm{Kg}{ }^{-1}\right), \mathrm{Mn}\left(104.26 \mathrm{mg} \mathrm{Kg}^{-1}\right)$ and $\mathrm{Cu}\left(1.97 \mathrm{mg} \mathrm{Kg}^{-1}\right)$ in comparison to other vegetable sources as kale or cauliflower that have up to three times less amounts of these minerals (Kawashima \& Valente-Soares, 2003; Kmiecik et al., 2007). It is remarkable that the concentration obtained for Fe was higher than in lentils, a traditional vegetable source for iron nutrition. In fact, in this study iron levels were two times higher than those found in some lentils varieties (Wang et al., 2009). Furthermore, in our results can be observed that concentration of $\mathrm{Fe}$ and $\mathrm{Zn}$ are significantly higher in inflorescences from capsulated than from control.

In our results, a general decrease of mineral content was observed when broccoli samples were cooked under high pressure. Similar results were showed by Kmiecik et al. (2007) in broccoli and cauliflower. Moreover, also a slight decrease of mineral content occurred when broccoli samples were cooked in a microwave oven showing a very similar behaviour than that obtained by López-Berenguer et al. (2007). In general, $\mathrm{Na}, \mathrm{K}, \mathrm{Ca}, \mathrm{Mg}$ and $\mathrm{Zn}$ showed a small percentage of losses. Iron losses depended of the cooking process and $\mathrm{Cu}$ and $\mathrm{Mn}$ showed lower values of these minerals after any type of cooking. On the other hand, steaming was the treatment that maintained the higher values in mineral content in almost all cases followed by microwaving. However, high pressure showed the lower mineral content for almost all the minerals analysed after cooking. All these results indicate that the retention of minerals in broccoli florets were higher in streaming than in microwave and high-pressure.

The results showed that encapsulation of seed improve germination and vegetative growth and final production. This may be due to greater absorption of $\mathrm{N}$ and $\mathrm{Fe}$ and higher fixation $\mathrm{C}$ that could be conferred to plant in the very early stage of germination. The higher $\mathrm{C}$ plant concentration in capsulated plants was related to high $\mathrm{ACO}_{2}$ and high Gs according to an increase in gas diffusion through stomata. In other side, broccoli has been revealed 
as a good source of the main mineral elements, such as $\mathrm{Na}, \mathrm{K}, \mathrm{Ca}$, and $\mathrm{Mg}$, and trace elements, such as $\mathrm{Fe}, \mathrm{Zn}$, $\mathrm{Mn}$ and $\mathrm{Cu}$, essential for human's beings. Significant higher amounts of $\mathrm{Fe}$ and $\mathrm{Zn}$ have been observed in inflorescences of plants coming from capsulated seed with the increase in the nutritional value. Cooking method have a high influence in retaining or losing cations showing that streaming give better results in retention than microwave and high pressure probably due to maintenance of tissue structures.

\section{Acknowledgements}

The authors thank Dr. David J. Walker, for correction of the written English in the manuscript. This work was supported by the following Spanish Ministry of Science and Innovation R\&D and innovation programs: AGL2012-40175-C02-01, "Ramón y Cajal" (Ref RYC-2009-04574). We also state that there is no conflict of interest in the information presented.

\section{References}

Agte, V. V., Tarwadi, K. V., Mengale, S., \& Chiplonkar, S. A. (2000). Potential of traditionally cooked green leafy vegetables as natural sources for supplementation of eight micronutrients in vegetarian diets. Journal of Food Composition and Analysis, 13, 885-891. http://dx.doi.org/10.1006/jfca.2000.0942

Almeida, C., \& Rocha, S. C. S. (2008). Coating process efficiency for polymer coated broccoli seeds in spouted bed. Engineering Agriculture, 28, 305-314.

Belizt, H. D., Grosch, W., \& Schieberle, P. (2004). Minerals. In H. D. Belizt, W. Grosch \& P. Schieberle (Eds.), Food Chemistry (pp. 427-433). Berlin: Springer.

Brugnoli, E., \& Lauteri, M. (1990). An evaluation of the effect of salinity on photosynthesis. In M. Baltscheffsky (Ed.), Current Research in Photosynthesis (Vol. IV, pp. 741-744). The Netherlands: Kluwer Academic Publishers. http://dx.doi.org/10.1007/978-94-009-0511-5_797

Farooq, M., Wahid, A., Kadambot, H., \& Siddique, M. (2012). Micronutrient application through seed treatments-a review. Journal of Soil Science and Plant Nutrition, 12, $125-142$. http://dx.doi.org/10.4067/S0718-95162012000100011

Flexas, J., Ribas-Carbó, M., Díaz-Espejo, A., Galmés, J., \& Medrano, H. (2008). Mesophyll conductance to $\mathrm{CO}_{2}$ : Current knowledge and future prospects. Plant Cell Environment, 31, 602-621. http://dx.doi.org/10.1111/j.1365-3040.2007.01757.x

Geissler, N., Hussin, S., \& Koyro, H. W. (2009). Interactive effects of NaCl salinity and elevated atmospheric $\mathrm{CO}_{2}$ concentration on growth, photosynthesis, water relations and chemical composition of the potential cash crop halophyte Aster tripolium L. Environmental and Experimental Botany, 65, $220-231$. http://dx.doi.org/10.1016/j.envexpbot.2008.11.001

Grusak, M. A., \& Cakmak, I. (2005). Methods to improve the crop delivery of minerals to human and livestock. In M. R. Broadley \& P. J. White (Eds.), Plant Nutritional Genomics (pp. 265-286). Blackwel.

Halmer, P. (2008). Seed technology and seed enhancement. Acta Horticulturae, 771, 17-26.

Huskisson, E., Maggini, S., \& Ruf, M. (2007). The role of vitamins and minerals in energy metabolism and well-being. Journal of International Medical Research, 35, 277-289. http://dx.doi.org/10.1177/147323000703500301

Kawashima, L. M., \& Valente-Soares, L. M. (2003). Mineral profile of raw and cooked leafy vegetables consumed in Southern Brazil. Journal of Food Composition and Analysis, 16, 605-611. http://dx.doi.org/10.1016/S0889-1575(03)00057-7

Kmiecik, W., Lisiewska, Z., \& Korus, A. (2007). Retention of mineral constituents in frozen brassicas depending on the method of preliminary processing of the raw material and preparation of frozen products for consumption. European Food Research and Technology, 224, 573-579. http://dx.doi.org/10.1007/s00217-006-0337-6

Koplik, R., Mestek, O., Kominkova, J., Borkova, M., \& Suchanek, M. (2004). Effect of cooking on phosphorus and trace elements species in peas. Food Chemistry, 85, 31-39. http://dx.doi.org/10.1016/j.foodchem.2003.05.004

López-Berenguer, C., Carvajal, M., Moreno, D. A., \& García-Viguera, C. (2007). Effects of microwave cooking conditions on bioactive compounds present in broccoli inflorescences. Journal of Agricultural and Food Chemistry, 55, 10001-10007. http://dx.doi.org/10.1021/jf071680t 
Lucarini, M. Canali, R. Cappelloni, M., Di Lullo, G., \& Lombardi-Boccia, G. (1999). In vitro calcium availability from brassica vegetables (Brassica oleracea L.) and as consumed in composite dishes. Food Chemistry, 64, 519-523. http://dx.doi.org/10.1016/S0308-8146(98)00159-9

Lukaski, H. C. (2004). Vitamin and mineral status: Effects on physical performance. Nutrition, 20, 632-644. http://dx.doi.org/10.1016/j.nut.2004.04.001

Martínez-Ballesta, M. C., Dominguez-Perles, R., Muries, B., Alcaraz-López, C., Moreno, D. A., García-Viguera, C., \& Carvajal, M. (2010). Plant mineral content and their role in promoting human health. Agronomy for Sustainable Development, 30, 295-309. http://dx.doi.org/10.1051/agro/2009022

Miyazawa, M., Nishiguchi, T., \& Yamafuji, C. (2005). Volatile components of the leaves of Brassica rapa L. var. perviridis Bailey. Flavor Frag Journal, 20, 158-160. http://dx.doi.org/10.1002/ffj.1335

Morgan, K. T. (2008). Nutritional determinants of bone health. Journal of Nutrition Elder, 27, 3-27. http://dx.doi.org/10.1080/01639360802059670

Mota-Cadenas, C., Alcaraz-López, C., Martínez-Ballesta, M. C., \& Carvajal, M. (2010). How salinity affects $\mathrm{CO}_{2}$ fixation by horticultural crops. Horticultural Science, 45, 1798-1803.

Osler, M., Heitmann, B. L., Gerdes, L. U., Jorgensen, L. M., \& Schroll, M. (2001). Dietary patterns and mortality in Danish men and women: A prospective observational study. British Journal of Nutrition, 85, 219-225. http://dx.doi.org/10.1079/BJN2000240

Puupponen-Pimia, R., Hakkinen, S. T., Aarni, M., Suortti, T., Lampi, A., Eurola, M., ... Oksman-Caldentey, K. (2003). Blanching and long-term freezing affect various bioactive compounds of vegetables in different ways. Journal of the Science of Food and Agriculture, 83, 1389-1402. http://dx.doi.org/10.1002/jsfa.1589

Rickman, J. C., Bruhn, C. M., \& Barrett, D. M. (2007). Review Nutritional comparison of fresh, frozen, and canned fruits and vegetables II. Vitamin A and carotenoids, vitamin E, minerals and fiber. Journal of the Science of Food and Agriculture, 87, 1185-1196. http://dx.doi.org/10.1002/jsfa.2824

Scott, J. M. (1989). Seed coating and treatments and their effects on plant establishment. Advances in Agronomy, 42, 43-83. http://dx.doi.org/10.1016/S0065-2113(08)60523-4

Shenkin, A. (2008). Basics in clinical nutrition: Physiological function and deficiency states of trace elements. e-SPEN, 3, 255-258. http://dx.doi.org/10.1016/j.eclnm.2008.06.003

Sobotka, L., Allison S., \& Stanga, Z. (2008). Basics in clinical nutrition: Water and electrolytes in health and disease. e-SPEN, 3, 259-266. http://dx.doi.org/10.1016/j.eclnm.2008.06.004

Someya, N., Tsuchiya, K., Yoshida, T., Noguchi, M. T., \& Sawada, H. (2007). Encapsulation of cabbage seeds in alginate polymer containing the biocontrol bacterium Pseudomonas florescens strain LRB3W1 for the control of cabbage soilborne diseases. Seed Science Technology, 25, 371-379. http://dx.doi.org/10.15258/sst.2007.35.2.12

Theobald, H. (2008). Dietary calcium and health. Nutrition Bulletin, 30, 237-277. http://dx.doi.org/10.1111/j.1467-3010.2005.00514.x

Vallejo, F., Tomás-Barberán, F. A., \& García-Viguera, C. (2002). Glucosinolates and vitamin C content in edible parts of broccoli florets after domestic cooking, European Food Research and Technology, 215, 310-316. http://dx.doi.org/10.1007/s00217-002-0560-8

Vallejo, F., Tomás-Barberán, F. A., \& García-Viguera, C. (2003a). Health promoting compounds in broccoli as influenced by refrigerated transport and retail sail period. Journal of Agricultural and Food Chemistry, 51, 3029-3034. http://dx.doi.org/10.1021/jf021065j

Vallejo, F., Tomás-Barberán, F. A., \& García-Viguera, C. (2003b). Phenolic compound contents in edible parts of broccoli inflorescences after domestic cooking. Journal of the Science of Food and Agriculture, 83, 1511-1516. http://dx.doi.org/10.1002/jsfa.1585

Van Groenigen, J. W., \& Van Kessel, C. (2002). Salinity-induced patterns of natural abundance carbon-13 and nitrogen-15 in plant and soil. Soil Science Society of America Journal, 66, 489-498. http://dx.doi.org/10.2136/sssaj2002.0489

Wang, N., Hatcher, D. W., Toews, R., \& Gawalko, E. J. (2009). Influence of cooking and dehulling on nutritional composition of several varieties of lentils (Lens culinaris). Food Science and Technology, 42, 842-848.

Welch, R. M., \& Graham, R. D. (2004). Breeding for micronutrients in staple food crops from a human nutrition 
perspective. Journal of Experimental Botany, 55, 353-364. http://dx.doi.org/10.1093/jxb/erh064

Welch, R. M., Combs, Jr. G. F., \& Duxbury, J. M. (1997). Toward a 'green' revolution. Issues of Science and Technology, 14, 50-58.

Williams, F. H. (2008). Neuromuscular complications of nutritional deficiencies. Physical medicine and rehabilitation clinics of North America, 19, 125-148. http://dx.doi.org/10.1016/j.pmr.2007.10.006

Wilson, C., Liu, X., Lesch, S. M., \& Suarez, D. L. (2006). Growth response of major USA cowpea cultivars II. Effect of salinity on leaf gas exchange. Plant Science, 170, 1095-1101. http://dx.doi.org/10.1016/j.plantsci.2006.01.010

Yang, X. H., \& Lu, C. M. (2005). Photosynthesis is improved by exogenous glycinebetaine in salt-stressed maize plants. Physiologia Plantarum, 124, 343-352. http://dx.doi.org/10.1111/j.1399-3054.2005.00518.x

\section{Copyrights}

Copyright for this article is retained by the author(s), with first publication rights granted to the journal.

This is an open-access article distributed under the terms and conditions of the Creative Commons Attribution license (http://creativecommons.org/licenses/by/3.0/). 